\title{
22 Transforming a Match Factory into the American Philatelic Research Library in Bellefonte, Pennsylvania
}

\begin{abstract}
The American Philatelic Research Library, one of the largest libraries in the world specializing in stamp collecting and postal history, opened its new library in 2016. The library attracts researchers from around the world, yet it was constructed in the unlikely location of an abandoned match factory building at the edge of a small town, Bellefonte, in central Pennsylvania, hundreds of miles from a major metropolitan area. Throughout the renovation process and library opening, the library built and strengthened connections with the community of researchers around the world who use its resources, and with the local community. The architect's design concept for the project was to produce a state-of-theart complement to the historical factory exterior. The new library unites collections which had previously been housed separately and adds functional elements such as a rare book room, exhibition space, work areas with individual reading lights and power outlets, along with accessibility features. The story of how the library found its new home and how it built support for the renovation project by engaging with its own history and the local history of Bellefonte, demonstrates the power of the library as place and can inform future library building projects worldwide.
\end{abstract}

Keywords: Special libraries - United States; Library buildings - Design and construction; Factories - Remodelling for other use

\section{Introduction}

Hundreds of people gathered in the atrium of the American Philatelic Research Library's new home to celebrate its grand opening on 2 November, 2016. At one end of the atrium, a ribbon stretched across a grand central staircase, awaiting the ceremonial cutting to officially open the library. Neat rows of bookshelves lined both sides of the atrium, and two spacious desks flanked the entrance. Behind the staircase, armchairs upholstered in dark hues clustered around low tables. Some furniture had been removed to make room for the grand opening ceremony, but visitors on a normal day would see long wooden tables with shaded reading lamps in the atrium at the foot of the staircase. In short, the space contained everything to be expected of a research library. Surrounding the traditional library

Ә Open Access. (02021 Tara Murray Grove, published by De Gruyter. (c) BY-NC-ND This work is licensed under the Creative Commons Attribution-NonCommercial-NoDerivatives 4.0 International License. 


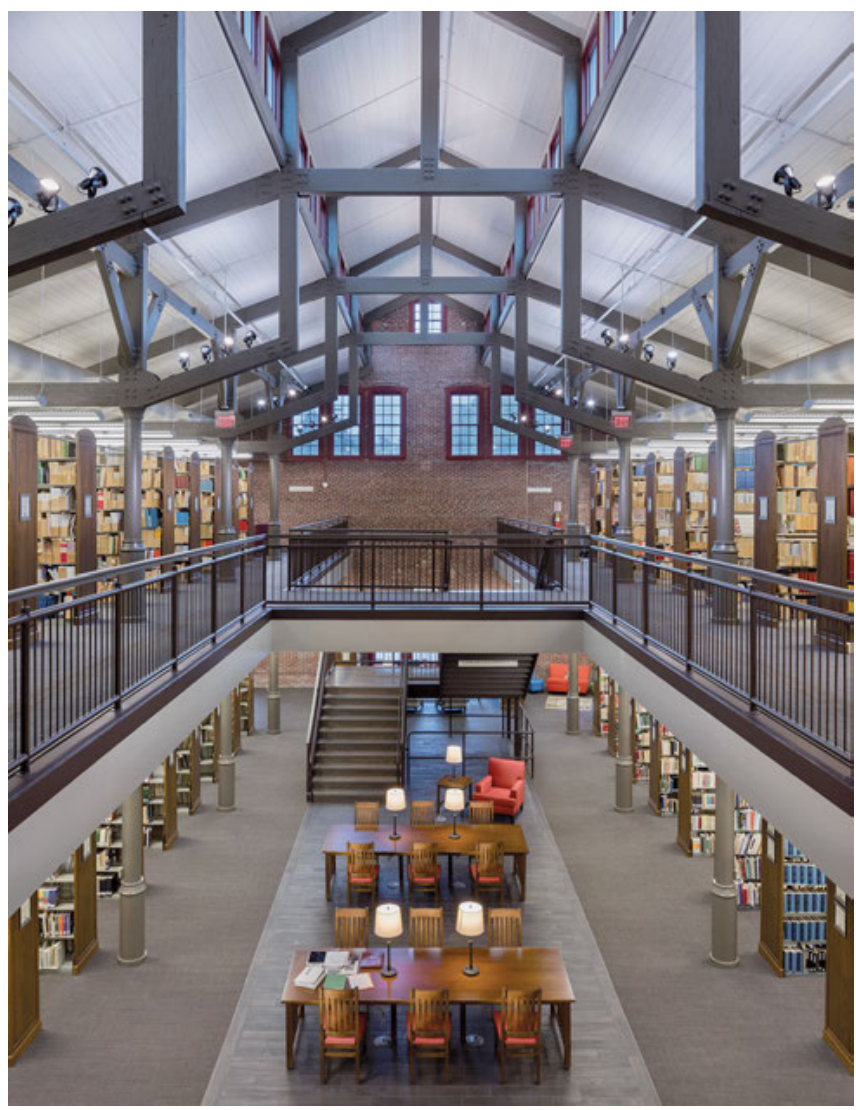

Fig. 1: The new American Philatelic Research Library reading room. (C) Pieper O’Brien Herr Architects.

\section{Facts and Figures}

Name: American Philatelic Research Library

Address: 100 Match Factory Place, Bellefonte, PA 16823 USA

Website: http://stamplibrary.org

Opening: October 2016

Builder: Veronesi Building and Remodeling Inc. https://www.vbrinc.com/

Architect: Pieper O'Brien Herr Architects https://poharchitects.com/

Gross floor area: $22,400 \mathrm{sq} \mathrm{ft}$

Main floor space: $19,000 \mathrm{sq} \mathrm{ft}$

Collection size: 90,000

Staff: 5

Workstations: 100

Building costs: US $\$ 4,900,000$ 
fixtures, though, stood the exposed brick walls of a century-old factory building. Sections of variously coloured bricks and different shades of mortar hinted at modifications and repairs made to the building over decades of industrial use.

In the crowd that Saturday, local politicians mingled with stamp collectors, some of whom had travelled great distances for the event, as reporters from philatelic magazines and local newspapers jotted down notes. The philatelists in the crowd attended to celebrate a testament to the enduring appeal of stamp collecting, or to be among the first researchers in one of the world's largest libraries dedicated to stamp collecting and postal history. Some in the crowd, who were neither stamp collectors nor researchers, simply wanted to witness the longawaited completion of renovations to an historic building at the edge of a town eager for revitalization.

The library's elegant new home (Figure 1) was once a factory for making matches, part of a thriving industrial district. The story of how a special library that draws researchers from all over the world came to be located in an old factory building is intertwined with the history of America's largest stamp collecting organization and the evolution of a former industrial town. The effort to complete the library drew on support from the philatelic community, the library community and the local community; the library's grand opening celebrated all of these.

\section{The American Philatelic Research Library}

The mission of the American Philatelic Research Library (APRL) is to maintain a philatelic library for stamp collectors and postal historians and to offer services "that promote knowledge, research and education of all aspects of stamp collecting, postal history and postal operations" (American Philatelic Research Library 2011, 1). The APRL is a membership library, serving the 27,000 members of the American Philatelic Society (APS) and individuals who join the library separately. It is also open to the public and provides services without any membership requirement, primarily to stamp collectors, stamp dealers and auction houses, historians, journalists and the local community. Non-members have access to all library services, except direct borrowing privileges, and pay an additional fee for some services. The APRL participates in sharing of library resources through interlibrary loan, mainly as a lender, and portions of its holdings are listed in the OCLC WorldCat database.

The APRL is incorporated independently with its own governance, but in practice has a symbiotic relationship with the APS, the national organization for stamp collectors in the United States. The APS has provided a library as a member 
service for most of its existence, and early library initiatives predate the creation of the APRL in 1968. When the APS was founded in 1886 as the American Philatelic Association, it included a library department and the first group of officers appointed included a librarian (Davidson 1986a, 128). The first library collection was built through donations from members and publishers. It resided with the volunteer librarian, requiring a transfer of the collection each time a new librarian was appointed. Books and journals were circulated by mail to members, an arrangement that did not seem to work as well as anticipated. In 1897, the librarian reported "that during the past year there has been practically no use made of the Library" (Deats 1897). The collection was transferred to the Carnegie Institute (now the Carnegie Library of Pittsburgh) and members who lived in Pittsburgh agreed to mail books to members from other areas and to return them to the library when they were mailed back (Deats, Krauth, and Severn 1897). By the 1920s, the arrangement had proved unsatisfactory, and in 1928 the APS left the collection at the disposal of the Carnegie Library of Pittsburgh (Davidson 1986b, 674), where at least some of the original books still reside.

For the next four decades, the APS was without a library, but in the 1960s interest in a lending library resurged, and in 1968 the APRL was incorporated independently as an affiliate of the APS ("Philatelic Literature Association Merger with American Philatelic Research Library” 1969). The APRL officially opened for business in 1972 with the completion of the first American Philatelic Building in State College, Pennsylvania. The building was owned by the APRL and co-occupied by the APS and APRL, an arrangement that would continue through a second American Philatelic Building in State College and the current American Philatelic Center in nearby Bellefonte, Pennsylvania. By the 1980s, the APS and APRL had outgrown their first building and a second American Philatelic Building was built and opened in State College in 1982. The second building was later expanded, but the APRL collection continued to grow and the library space quickly reached capacity.

When, at the beginning of the $21^{\text {st }}$ century, the APS and APRL found themselves once again in need of more space, the APRL purchased a vacant factory, originally constructed by the Pennsylvania Match Company and known locally as the Match Factory complex, from the Borough of Bellefonte and began the renovation of a new home for itself and the APS. The Match Factory complex, consisting of eighteen mostly connected buildings, was larger than the space required by the APS and the APRL, and the APRL planned to lease out the unneeded space. For three decades, the APS and APRL had occupied buildings designed and built specifically for their needs. Renovating a century-old building and becoming a landlord presented a new way of operating. The move was welcomed by the local community in Bellefonte, which had been waiting for nearly a decade for 
someone to buy and renovate the abandoned buildings, but it was met with scepticism by some in the stamp collecting community.

\section{A Home for Philately in Central Pennsylvania}

State College had always been a surprising location for the headquarters of "America's Stamp Club," as the APS is sometimes called. Located in central Pennsylvania, a half day's drive from major cities such as Philadelphia or Washington, DC, the population was about 100,000 according to the 2000 Census. The town grew up around the Pennsylvania State University (Penn State), founded in 1855 and still the region's major employer. It was a far cry from, for example, the urban home of the Royal Philatelic Society London, the UK's national stamp collecting organization.

But the APS, and later APRL, had called State College home since the hiring of the first staff member, who happened to live in State College, and the establishment of the first APS office on the second floor of a downtown building in the 1940s. When the society moved to its own building, the headquarters and library became a destination for stamp collectors from near and far as well as for the local population. A portion of the APS membership, however, was left wondering why their society could not be located in a larger city, with access to an international airport and proximity to cultural attractions and relevant institutions such as the National Postal Museum in Washington, DC.

It was not surprising, then, that when the APS and APRL decided to purchase an abandoned factory building 10 miles from State College in Bellefonte, population 6,395 per the 2000 Census, the membership needed to be convinced that the move was a good idea. State College already appeared remote and rural to many APS members; Bellefonte, despite its designation as the county seat, was much smaller. The Match Factory had lain vacant since 1996 and would require extensive renovations before the APS and ARPL could move in (Figure 2). The purchase and renovations would incur large debts for the two non-profit organizations, at a time when interest in stamp collecting appeared to be waning and APS membership was declining. The town of Bellefonte, like many towns in Pennsylvania, had experienced flooding in the aftermath of Hurricane Agnes in 1972. The history evoked concern that the banks of the nearby creek would overflow and flood the building. Although reuse of existing structures has been recognized as a sustainable practice, some worried that the Match Factory would require too much work to provide a suitable home for the APS and APRL. Nevertheless, the APS and APRL had long outgrown their 25,000-square-foot building in State College, and the library needed additional space to house its growing collection. 


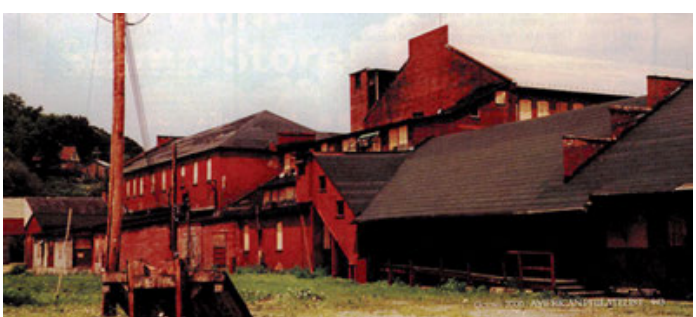

Fig. 2: The Match Factory complex at the time of the purchase in 2000. Reprinted with permission from The American Philatelist, 114 (10): 943.

Despite the concern expressed in meetings and in the pages of philatelic magazines, after extensive research, the APS and APRL proceeded with the purchase. APS leadership described the advantages of the new location to win member support. For example, the February 2002 issue of The American Philatelist, the monthly publication of the APS, contained an article on the history of Bellefonte, which, well into the $20^{\text {th }}$ century, boasted a larger population than the nearby college town (Wunderly 2002). In a November 2000 editorial for the society's monthly magazine, APS President Peter P. McCann attempted to allay member concerns about the APS and APRL taking on the duties of a landlord:

One of the criticisms that was raised in the debate about whether the APS should acquire the property or not was that some people felt that the APS should not become a landlord as a non-profit society. Many non-profits already are major landlords as a means of investing for the future, and in actual fact there is really no practical difference in investing in mutual funds, U.S. government securities, or real estate, which in our case would be buildings the APS also happens to occupy. (McCann 2000, 1035)

\section{The Match Factory}

The first construction of what is now the Match Factory complex began in 1899 to house the new Pennsylvania Match Factory. As the company expanded its operations, the complex grew, and by 1931, it had reached its present size of eighteen buildings. The complex operated as a match factory under several names and owners until 1947, when economic conditions forced its closure, and the property was purchased and used as a warehouse by a local lumber company. In 1996, entrepreneurs purchased the complex with plans to use it as a brewery, but the group failed to raise the necessary funding and in 2000 the Borough of Bellefonte took ownership of the property.

Bellefonte was eager to revitalize its waterfront district, which was roughly delineated on one end by the looming façade of the four-story Match Factory and its brick smokestack. When the municipality purchased the Match Factory, it did 
so with the intent of preserving the building and putting it to use. As the sale was underway, Bellefonte applied to have the property listed on the National Register of Historic Places and formed a committee to find suitable tenants for the building (Urch 2000). The historic registry listing ensured preservation of the building and made tax credits to facilitate the sale available. Later, when the APS expressed interest in purchasing the property for its headquarters, Bellefonte committed to expanding nearby Talleyrand Park, a centrepiece of the waterfront district, to connect the Match Factory to downtown Bellefonte. The land in between the existing park and the Match Factory was overgrown and unused at the time of the sale, contributing to the property's derelict appearance (Figure 2).

Once the sale was finalized and sufficient renovations completed, the APS and APRL moved their operations into the Match Factory. The local newspaper reported that "Bellefonte officials and residents see the society's decision to renovate the Match Factory as a large boost to efforts to revitalize the borough's waterfront district" (Dobo 2004, A1). When the move was finished, Bellefonte threw a party complete with concerts, banquets, garden parties and trolley rides to celebrate the potential influx of visitors to the town (CDT Editorial Staff 2004).

The Match Factory's importance to Bellefonte extends beyond the economic value of the property. At its height, the factory employed hundreds of people, and many of the workers' descendants still reside in Bellefonte. The author of a report prepared for the Borough of Bellefonte and the Pennsylvania Historical and Museum Commission found that "the residents of Bellefonte take pride in their history, and understand the important role that industry played in the development of the community" (Hammerstedt 2005, 63). The report noted that many of Bellefonte's industrial resources had been removed and urged the preservation of those that remained. ${ }^{1}$

The opening of the new APS headquarters in the Match Factory was voted one of the top ten stories of the year by readers of the Centre Daily Times, State College's newspaper. To this day, many people who come to tour the APS and APRL facilities have little or no interest in philately and just want to see the renovated factory.

1 At the time of the report's preparation, the APS had already purchased and moved into the Match Factory, although renovations of the complex were not yet complete. 


\section{Match Factory Renovations}

The renovations to the Match Factory were planned as several distinct projects, with the library renovation taking place in the last phase. The first phase included 22,000 sq ft for tenant space in a concrete block building that had been added to the complex in the 1960s, after factory operations had ceased. Once tenants began occupying part of the complex, rent income helped to offset the debt incurred by the building purchase and allowed for continued work on the property. The second phase of renovations included two historic buildings and a connection to the block building, providing the space needed for the APS and the APRL to move into the Match Factory in 2004.

With the renovations for its permanent home still several renovation phases in the future, the APRL moved into temporary library space, which it occupied for twelve years. The space, approximately $12,000 \mathrm{sq} \mathrm{ft}$, provided a little breathing room after the cramped conditions in the previous State College location, but it proved inadequate for material in the APRL's collections. To accommodate more shelving, the stacks were placed closer together than the spacing recommended by library accessibility standards, making it impossible for staff to push book carts between the rows and difficult for researchers to access the collection. Despite the attempts to conserve space, the shelves were soon overflowing once again. The library lacked office space beyond the librarian's office which doubled as a rare book room, and a few desks hidden behind the reference shelves. Volunteers were forced to work in the centre of the library where they competed with researchers for limited table space. Portions of shelving units had to be removed to accommodate support columns.

During this time, the library stored about half of its physical collections in a warehouse space in another location in the complex which placed the collections in jeopardy and complicated the library's operations. The warehouse lacked adequate climate control and though connected by an interior hallway, its distance from the main library made it difficult for staff to catalogue materials and retrieve them for researchers. The space was also used for other storage purposes by the APS, which created security concerns. Subsequent renovation for tenant space on the floors above the warehouse produced dust which later had to be cleaned from library materials, and a new hallway for tenant access reduced the amount of space available for library storage. Addressing these challenges would become a priority when the library renovation finally began years later.

While the APS and APRL occupied the complex, renovations continued. A third phase provided additional event space for the APS and APRL. The shared space would eventually be used for a banquet to celebrate the grand opening of the APRL. The fourth phase included expanded tenant space and a structure 
built to take advantage of the opportunity to acquire, via a loan from the National Museum of American History, the historic Headsville, West Virginia post office and general store. The APS operates the post office, which was depicted on a 1972 US stamp commemorating the $100^{\text {th }}$ anniversary of mail order, as a contract postal station and stocks it with items similar to those that would have appeared on the shelves during its operation in the latter half of the $19^{\text {th }}$ century. The post office is a popular stop for collectors and non-collectors alike, and employees at tenant businesses enjoy the convenience of buying stamps and sending mail close by their offices.

Subsequent renovation phases included more tenant space, and the final tenant, a distillery, opened for business in 2015. The distillery, Big Spring Spirits, achieved Leadership in Energy and Environmental Design (LEED) Gold certification from the US Green Building Council. In addition to a sustainable distilling process, the certification factored in the reuse of an historic building and the maintenance of interior non-structural elements, such as walls, flooring and ceilings. The design of the APRL incorporated similar principles, although most interior elements in the library space were unsalvageable by the time renovations commenced.

Following the renovation phases already described, the only remaining unrenovated space was that designated from the outset as the permanent home of the APRL: the two buildings labelled Building Three and Building Four on schematics. In the intervening years, however, a dwindling APS membership and a national recession combined to place economic pressure on the APS and APRL and delay the library renovation.

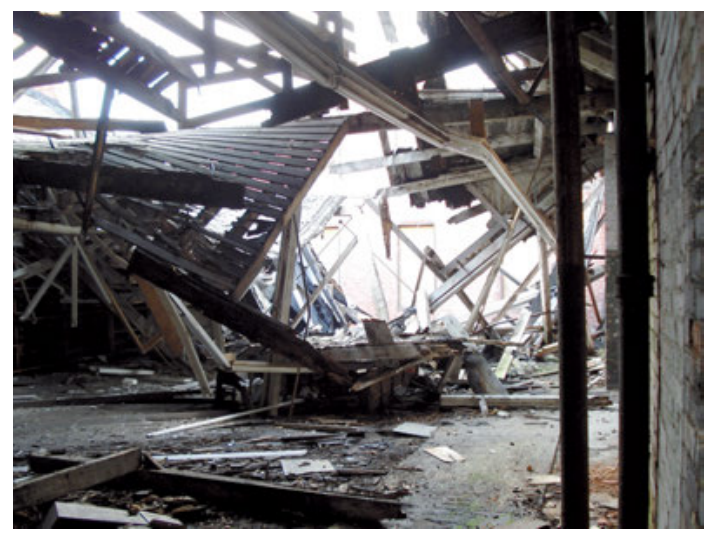

Fig. 3: The American Philatelic Research Library space before renovations. (C) Pieper O’Brien Herr Architects.

The library construction was completed in phases, partly to address funding concerns. The first phase included the closed stacks, map room and rare book room 
on the second floor of the new library space in Building Four, the smaller of the two adjacent buildings (Figure 7). The closed stacks area was fitted out with compact shelving to store archives, second copies and other less frequently consulted material. The completion of the first phase of the library renovation allowed for the transfer of material out of the problematic warehouse storage. While the material was still not co-located with the rest of the library collection and the staff, it was at least finally on library shelving, in climate-controlled space, secure, and separate from non-library storage. The next phase would include all of the larger Building Three, which occupied a central location in the complex but had suffered severe damage due to a partially collapsed roof and the cumulative effects of weather. The threat of further damage to the unprotected building put additional pressure on the APRL to complete the library project. On the day the architect toured the site, fresh snowfall lay on the ground inside the building, and the interior floor structure had completely collapsed (Figure 3).

\section{The Library Design}

The Match Factory façade, rising up behind the railroad tracks at the edge of the picturesque Talleyrand Park, is one of the iconic images of Bellefonte. It serves as a backdrop for community celebrations and wedding photographs in the park. The two buildings that comprise the new APRL, Building Three and Building Four, together with Building Five, a four-story building used for tenant space, and a tall brick smokestack, form the skyline. The name of one of the later iterations of the Match Factory, Universal Match Corporation, is painted across the three buildings (Figure 4).

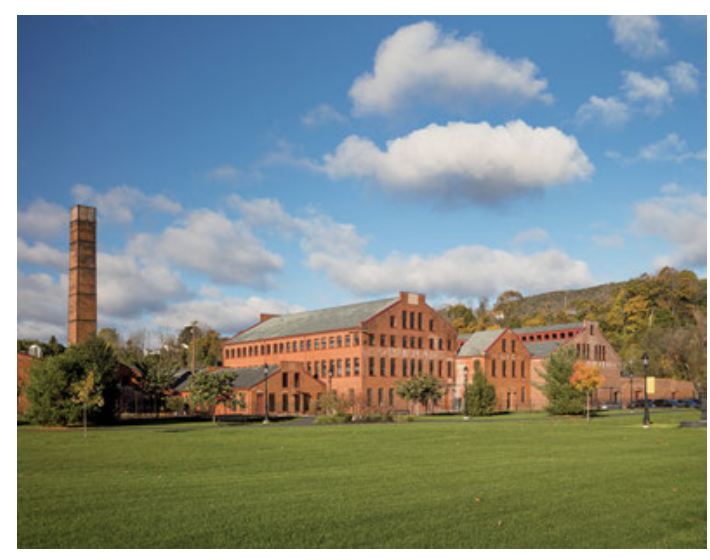

Fig. 4: The exterior of the Match Factory as seen from Talleyrand Park. (C) Pieper O’Brien Herr Architects. 
The APRL project was designed by Pieper O'Brien Herr Architects. The principal architect, Charles J. O'Brien III, is an APS member and familiar with Society and library operations and the needs of the membership. The design team worked closely with library staff throughout the project, ensuring that the design facilitated library operations and accommodated naming opportunities for donors. Because of the property's historic designation and location inside an historic district, the project had to be approved by Bellefonte's Historic Architectural Review Board. Two goals guided the design: to produce a state-of-the-art library facility accommodating staff and researcher needs; and to follow an historical theme complementing the building's exterior.

For most of the year, the APRL serves most of its researchers remotely. Staff handle requests by telephone or email, retrieve materials, scan short passages and images, and send books on loan by mail. While significant digitization efforts are underway, including APRL projects, philatelic literature lags behind many other fields in this respect, and most of the material is in paper format. For their work, staff require proximity to physical collections, access to scanning equipment and workspace for processing book loans by mail.

On a typical day, the APRL might see only a handful of visiting researchers, but during special events such as the APS Summer Seminar week of educational offerings, the library can be crowded with researchers. The new library space had to be able to accommodate occasional influxes with adequate seating for individual work and small groups. Library staff asked for spaces tailored to the needs of researchers travelling to visit the library for extended periods, such as carrels with lockable storage.

The final design incorporated elements to facilitate the specialized operations of the APRL while retaining its focus on the historic theme. Throughout the project, the architect strove to preserve history and promote sustainability through reuse and restoration, and any new materials required were selected with a period look and feel. In an email to the author on 9 November, 2019, O'Brien described the interior design concept for the project:

The architects believed it was important from the outset that the interior should look like it had always been this way. The massive existing brick walls were designed to remain exposed to view. The entire floor and roof structure were replaced, in part due to the poor condition of the existing wood structure. The new replacement structure was designed from the outset to handle the heavy library loads yet closely resemble a historic period structure. The new wood trusses were designed to be reminiscent of the former structure in shape and form. The new steel columns were articulated with period details to mimic an iron column from a former era, possibly a style that could have been used when the original structure was built. Other modern materials were selected to further emulate the historic fabric. A 'wood look' porcelain floor for the area under the atrium was a vitally important piece of 
the design. This flooring looks like wood, but has a permanent, easy-to clean surface that will be longer lasting and more durable than actual wood. In addition, a special ceiling was needed. The pressed ceiling tiles have the visual appeal of vintage copper yet also offer modern sound absorption characteristics. The flooring and ceiling products were replicated with modern high-tech materials. They offer the look and feel of the former materials' full glory yet do so without cost and maintenance issues.

The property's historic designation presented challenges during renovations. Nineteenth century factory buildings relied on natural light, but because the main library building, Building Three, is bordered by other buildings in the Match Factory complex on three sides, only one wall had windows. The architect envisioned a clerestory at the peak of the roof to provide natural light. The historic designation precluded any changes to the exterior, but the architect was able to demonstrate, using a picture postcard image (Figure 5), that a clerestory had previously existed on another part of the complex. The older clerestory had been removed prior to the APRL taking ownership of the property. Bellefonte's Historic Architectural Review Board approved the addition of a clerestory.

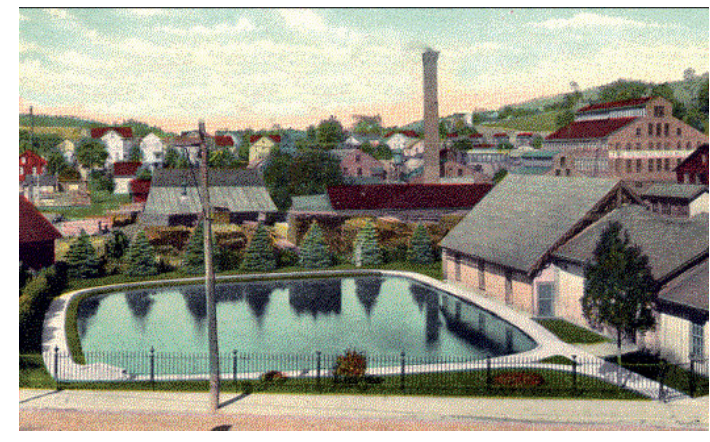

Fig. 5: Picture postcard showing the historic clerestory. (C) Fred D. Smith Collection.

The building's age and former industrial use presented other challenges. One corner of the library space was occupied by a three-story vault. Rather than attempt to remove the vault, the design repurposed it as an elevator shaft. On the hallway wall outside the library, the vault door hardware is preserved as a reminder of the building's past. Occasionally, construction workers discovered structural elements within interior walls that forced minor changes in the design, particularly to the new connections between Building Three and Building Four. 


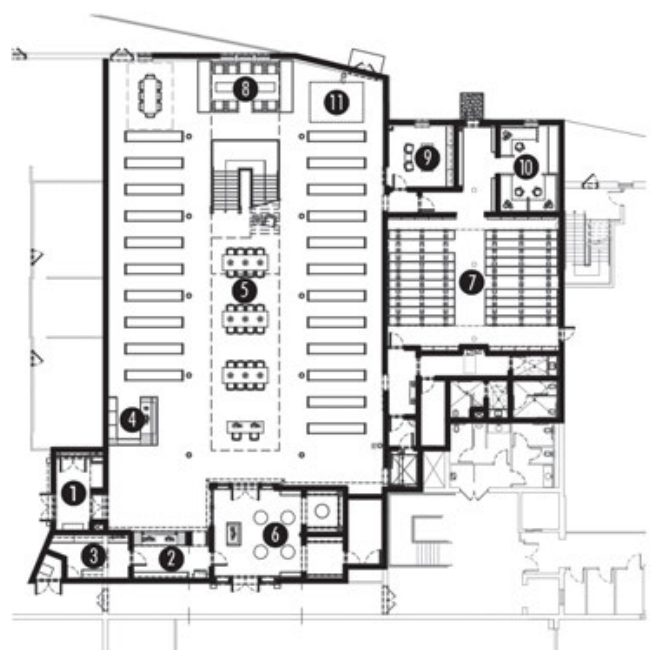

First Floor

1. Library Entrance

2. Circulation Desk

3. Work Room

4. Research Desk

5. Main Reading Room / Stacks

6. Gift Shop

7. Closed Stacks

8. Study / Lounge Area

9. Librarian Office

10. Library Staff

11. Youth Reading Area

Fig. 6: First floor plan. (C) Pieper O’Brien Herr Architects.

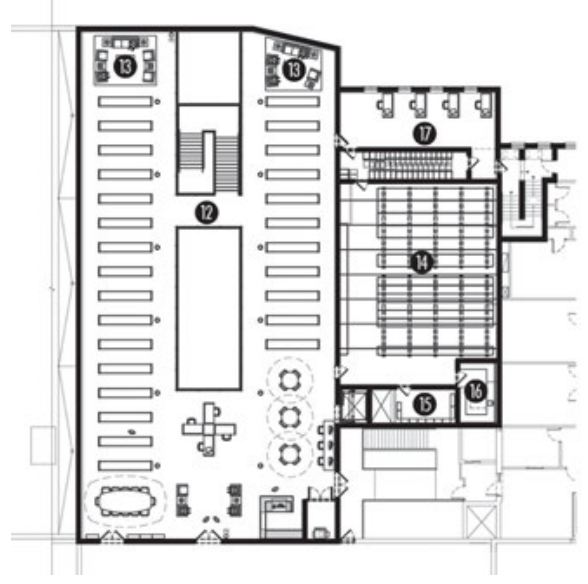

Second Floor

12.Second Floor Reading Room / Stacks

13.Study / Lounge Area

14. Closed Stacks

15. Rare Book Collection

16. Map Collection

17. Guest Research

Fig. 7: Second floor plan. (C Pieper O’Brien Herr Architects.

The new library design addressed practical concerns for the APRL. When the renovation was completed, APRL collections were finally, after decades of various separations due to space constraints, located in a contiguous and secure 19,000-square-foot facility (Figures 6 and 7). The rare book room was deliberately placed on the second floor to alleviate any lingering flooding concerns and allowed the rare book collection to be moved from the staff office where it had been stored. The new map room provided space for a flat file. As archival mate- 
rial quickly filled the compact shelving installed on the second floor of Building Four in the first phase of library renovations, a second closed stacks section of compact shelving was added to the first floor, to be used for the APRL's vast collection of philatelic auction catalogues. Interior walls were kept clear to provide display space for the library's collection of art works, and a separate gallery room for exhibits from the library's archives was added to the design. The design incorporated a variety of seating options to accommodate different uses of the library, including the long work tables already mentioned, smaller tables for individual or small group work, conference tables for informal meetings, carrels for quiet study, and soft seating areas near the exterior wall windows. All the work areas provide easy access to electrical power and task lighting. Throughout the design, the team incorporated accessible features in accordance with the Americans with Disabilities Act and American Library Association guidelines. The design paid particular attention to the spacing of the book stacks, which had been problematic in the temporary library space. In the early design stages, support columns were spaced to line up with the desired width of the library aisles. After careful consideration due to the cost involved, an elevator inside the library was added to the project to make the second floor of the library fully accessible and to enable staff to move book carts easily between the floors. In initial designs, the library would have relied on an existing elevator in another part of the complex.

The design team placed staff work areas in dispersed locations throughout the library to ensure researchers had access to assistance when needed. The cataloguer's desk is on the second floor, close to the journal collection and the second-floor closed stacks. The reference and circulation desks are positioned on either side of the entrance to welcome visitors, and the library director's office is at the rear of the library, with a window to the children's area and close access to a new private work area. The work area houses several workstations to ensure a comfortable working environment with secure storage for volunteers and interns.

Much of the funding for the library renovation came from private donors. To assist in fundraising, the design team incorporated library spaces with naming opportunities that would appeal to donors. The spaces included five reading lounges. For the final design, after consultation with the donor, one of the lounges was converted to a children's area to support APS youth programs and outreach to the local community. The APS Education Department helped to select appropriate furniture for the children's area. 


\section{Engaging the Community}

In addition to the symbiotic relationship between the APRL and the APS membership that was so critical to the Match Factory project, the new library helped the APRL to strengthen ties with other philatelic libraries throughout the world and with the local community of Bellefonte. Throughout the renovation project, the APRL engaged with its communities, and at the completion of the project, invited them to join in the celebration. The APRL had gained not only a physical home, but a community base to support future initiatives.

Although the APRL is one of the largest and most accessible collections of philatelic literature in the world, it is not the only library dedicated to stamps and postal history. The APRL hosts a union catalogue for North American philatelic libraries (http://catalog.stamplibrary.org) and is a founding member of the Global Philatelic Library (http://globalphilateliclibrary.org). Other philatelic libraries watched the developments at the Match Factory with keen interest, particularly those in North America who frequently consult the APRL to ensure that last copies are preserved or for help filling collection gaps. The APRL commits to collecting more comprehensively than other philatelic libraries, therefore other philatelic libraries rely on the APRL having enough space to serve as a repository. Attendees at the World Stamp Show 2016 in New York City got a sneak peak of the new APRL in a presentation, and the featured speaker for the APRL's grand opening banquet was David Beech, long-time curator of Philatelic Collections at the British Library and former president of the Royal Philatelic Society London.

The APRL has enjoyed close and collaborative relationships with its tenants. At the banquet celebrating the library's grand opening, the bar featured a gin cocktail created by the Match Factory's distillery, Big Spring Spirits. The custom cocktail was named the Inverted Jenny, a nod to the well-known US stamp error with the airplane printed upside-down. The Inverted Jenny has special meaning for the APRL because the library received, via a bequest, the title to four of the stamps which had been stolen from a display in the 1950s, and the sale of one of the stamps that was later recovered helped to finance the library renovation. ${ }^{2}$

Collaboration with Match Factory tenants, and benefits such as access to the contract postal station and event space rental, have proved to be beneficial for the APRL. Tenants who develop attachments to their Match Factory space fill long-term leases which increase the APRL's financial stability. Relationships with

2 The library still owns and displays one Inverted Jenny. The library's close relationship to the stamp is evident in several places in the new library. An image of the Inverted Jenny decorates the backs of wooden chairs in the children's area, and a model of the Curtiss Jenny biplane depicted on the stamp is suspended from the library's lofty second floor ceiling. 
the local businesses of the Match Factory also build bridges to the community of Bellefonte. These relationships have been key in positioning the APRL and APS as part of the Bellefonte community and not outsiders.

Perhaps the most successful avenue to engage the local community for the APRL has been through its historic building. The one exception to the APRL's policy to limit its collecting to materials related to philately or postal history is material related to the history of the Match Factory. The collection includes newspaper clippings, souvenirs and even a matchbox found by a construction worker during the renovation project. Within the APRL's Match Factory collection is a copy of a photograph of Match Factory employees. The APRL invited community members to identify the workers in the photograph. The APRL also collects envelopes and postcards related to Bellefonte, including some that predate the adoption of stamps for the payment of postage in 1847.

One APRL collection of particular interest to both postal historians and local history buffs is the Daniel Hines Air Mail Collection. The collection is the one most frequently consulted for non-philatelic purposes at the APRL. In 1918, when the U.S. Post Office Department initiated development of transcontinental air mail services, it needed a refuelling stop for its planes between New York and Cleveland. The post office selected Bellefonte, and an airfield was established on the site where the town's high school stands today. The archival collection was formed by Daniel Hines, whose brothers worked at the Bellefonte airfield. It was donated to the APRL by a family member soon after the library relocated from State College to Bellefonte. Bellefonte claims two distinctions in the story of the nation's air mail system: it was the first stop on the new route, and the most dangerous. The combination of changing weather and mountainous terrain caused numerous crashes, claiming the lives of 34 pilots. Bellefonte retained its prominence in national aviation for about a decade, until the post office handed over operation of the air mail routes to private contractors and advances in aviation lessened the need for refuelling stops.

When the APS and APRL moved into the Match Factory, a local retired Navy pilot, who had been searching for a place to erect a monument to the fallen air mail pilots, finally found an agreeable location (Wunderly 2018, 129). The granite memorial, dedicated in 2005, stands on the APRL property at the edge of Spring Creek. In 2007, the APS published a book by a local author based on research in the Hines Collection, Bellefonte and the Early Air Mail: 1918-1927. It is now in its second edition (Wunderly 2018) and has proved popular with local and philatelic audiences. Public libraries in Bellefonte and State College include it in their holdings, and it was featured in a broadcast by the local public radio station (Kochersperger 2008). The APRL incorporated local history prominently into its new 
physical presence with a display of maps and photographs from the Hines Air Mail Collection just outside the library entrance.

\section{Conclusion}

While the APRL is a unique case, other types of library construction projects can be informed by its story. Through its grand new library, the APRL created a place of pride and inspiration for the philatelic community and formed a bond with the local community by preserving and bringing new life to a landmark site.

Library collections, even when their focus is global, contain materials that help to tell the story of their local communities. For a university library, the materials might be the university archives, publications of faculty and students, or books about the local community; for a public library, local history and genealogical resources and publications by local authors relate to the local community; in a corporate library, the archives and records of the parent organization contribute to the story. The library's physical presence is a testament to the importance of its community's history and provides a gathering place for the community. Engaging the library's communities, through targeted collection-building, exhibits and programming, builds support for the library as place.

\section{Acknowledgments}

The author is grateful to the staff of the American Philatelic Research Library, and in particular to Scott Tiffney and Betsy Gamble, for research assistance, and to Bill Brockman, Henry Pisciotta, and Bryan Grove for insightful feedback.

\section{References}

American Philatelic Research Library. 2011. By-Laws: American Philatelic Research Library. Bellefonte, PA: American Philatelic Research Library. https://classic.stamps.org/userfiles/ file/library/Bylaws.pdf

CDT Editorial Staff. 2004. "A Wonderful Moment for Bellefonte.” Centre Daily Times, June 25, 2004.

Davidson, Robert L. D. 1986a. "APS: The First Century.” The American Philatelist 100 (2): 128-34.

Davidson, Robert L. D. 1986b. “APS: The First Century.” The American Philatelist 100 (7): 668-74. 
Deats, H. E. 1897. “Librarian's Report.” The American Philatelist 11 (November): 24.

Deats, H. E., C. P. Krauth, and C. E. Severn. 1897. "Report of Committee on Permanent Location of Library." The American Philatelist 11 (November): 24-25.

Dobo, Nichole. 2004. “New Tenant Begins Match Factory Move.” Centre Daily Times, May 19, 2004.

Hammerstedt, Erin. 2005. Industrial Heritage of the Bellefonte Waterfront District. Prepared for the Borough of Bellefonte and the Pennsylvania Historical and Museum Commission. [Not published].

Kochersperger, Steve. 2008. "BookMark: Bellefonte and Early Airmail: 1918-1927 by Kathleen Wunderly (American Philatelic Society).” WPSU Penn State [audio]. http://archive.wpsu. org/archives/bookmark-bellefonte-early-airmail-1918-1927-kathleen-wunderly-americanphilateli,1505

McCann, Peter P. 2000. “Match Factory Purchase - The Next Steps.” The American Philatelist 114 (11): 1035.

“Philatelic Literature Association Merger with American Philatelic Research Library.” 1969. Philatelic Literature Review 18 (4): 159-62.

Urch, Kakie. 2000. “Tenants Sought to Occupy Match Factory.” Centre Daily Times, February 14, 2000.

Wunderly, Kathleen. 2002. “Bellefonte: A History.” The American Philatelist 116 (2): 124-29.

Wunderly, Kathleen. 2018. Bellefonte and the Early Air Mail, 1918-1927. $2^{\text {nd }}$ ed. Bellefonte, PA: American Philatelic Society. 
